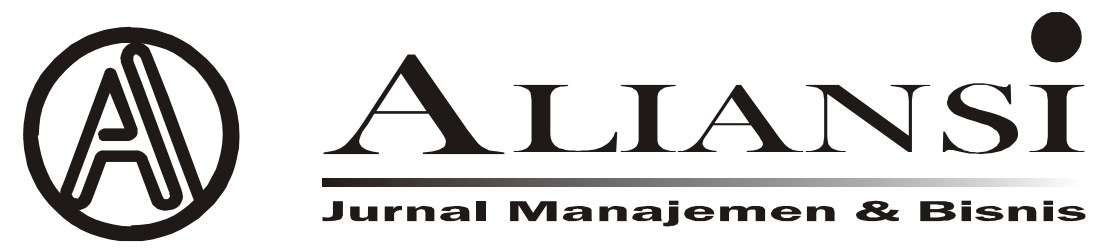

\title{
PENGARUH PROFITABILITAS DAN UKURAN PERUSAHAAN TERHADAP NILAI PERUSAHAAN DENGAN STRUKTUR MODAL SEBAGAI VARIABEL INTERVENING (STUDI PADA PERUSAHAAN ANEKA INDUSTRI YANG TERDAFTAR DI BEI 2012-2019)
}

Oleh : Fitri Diana Tri Anisa ${ }^{1}$ dan Indra Siswanti ${ }^{2 *}$

\begin{abstract}
The purpose of the research is to obtain empirical evidence about the impact of profitability, company size , capital structure on firm value. And the other purpose of this research too is to determine the effect of profitability, company size on firm value mediated by capital structure. The sample in this research is manufacturing company on Miscellaneous industry sector which listed in Indonesia Stock Exchange during the period of 2012-2019. With using purposive sampling data this research got twelve companies as sample research. The source of the data of this research was conducted from annual report and financial report.This research is using quantitative approach with path analysis method and using SmartPLS 3.0 as analyisis tool.The result in this research has two kind of result,for direct result found that profitabilty has significant positive effect on firm value, company size has significant positive effect on firm value, capital structure has significant negative effect to firmvalue. And the result for indirect result are Capital structure is able to mediate profitability on firm value. But on the other hand capital structure is not able to mediate company size on firm value.

Keyword: Profitabilty, firms size, capital structure, firm value.
\end{abstract}

\section{PENDAHULUAN}

Pada era digitalisasi yang semakin hari semakin canggih, kita tidak bisa mengelak akan perubahan yang semakin cepat. Lalu bagaimana dengan perekonomian?. Kondisi ekonomi global umumnya akan terus berkembang mengikuti perkembangan teknologi dan globalisiasi. Dapat dilihat dengan banyaknya aplikasi - aplikasi untuk berinvestasi yang sangat mudah untuk digunakan, bahkan untuk pemula sekalipun. Tentu saja itu berdampak baik bagi dunia investasi di Indonesia. Hal ini juga dirasakan oleh setiap perusahaan, terutama perusahaan yang sudah go public. Citra atau nilai suatu perusahaan menjadi sangat berarti, karena persaingan perusahaan yang sudah go public semakin ketat. Sehingga perusahaan perlu menjaga nilai perusahaannya dengan baik. Tujuan utama dari perusahaan sudah go public atau yang sudah terdaftar di BEI, yaitu untuk menghasilkan laba guna meningkatkan kemakmuran pemilik atau para pemegang saham melalui peningkatan nilai perusahaan yang mana dapat menggambarkan keadaan perusahaan. Seperti hal nya Elon Musk menjadi orang terkaya di dunia dalam beberapa waktu karena saham Tesla naik. Maka dari itu, bagi para investor nilai perusahaan sangat berarti (Gultom dkk ,2013).

Menurut Rahayu dan Sari (2018) Harga saham yang tinggi membuat nilai perusahaan juga tinggi, dan meningkatkan kepercayaan pasar tidak hanya terhadap kinerja perusahaan saat ini namun juga pada prospek perusahaan di masa mendatang. Pertumbuhan dan kinerja perusahaan menjadi hal yang penting dalam menilai suatu perusahaan. Kinerja perusahaan dapat diukur dengan cara yang berbeda dan dengan menerapkan berbagai metode. Metode yang umumnya digunakan adalah rasio profitabilitas (Niresh \& Velnampy, 2014).

\section{Research Gap}

Profitability perusahaan berhubungan positif dan signifikan terhadap nilai perusahaan. Di dalam mengelola aset untuk menghasilkan profit akan berdampak terhadap penelitian nilai perusahaan.Profit yang tinggi memberikan indikasi prospek perusahaan

1* Dosen Magister Manajemen Perbanas Institute Jakarta

2* Dosen, Fakultas Ekonomi dan Bisnis, Universitas Mercu Buana Jakarta 
yang baik, sehingga dapat memicu para investor untuk meningkatkan permintaan saham (Dhani \& Utama, 2017). Menurut Hermuningsih (2012), Sabrin dkk (2016) profitabilitas berpengaruh signifikan terhadap nilai perusahaan Sedangkan menurut Thaib dan Dewantoro (2017) Profitabilitas memiliki pengaruh negatif dan tidak signifikan terhadap nilai perusahaan. Hal ini berarti keuntungan suatu perusahaan tidak berpengaruh terhadap nilai perusahaan. Dan menurut Anton (2016) profitabilitas tidak memiliki pengaruh yang signifikan secara statistik pada nilai perusahaan.

Ukuran perusahaan adalah salah satu variabel yang dipertimbangkan dalam menentukan nilai suatu perusahaan.Ukuran perusahaan merupakan cerminan total dari aset yang dimiliki suatu perusahan (Rahayu \& Sari, 2018). Menurut Rahayu dan Sari (2018), Prasetia dkk (2016), Anung dkk (2017) Ukuran Perusahaan secara signifikan berpengaruh positif terhadap Nilai Perusahaan. Ini berarti setiap peningkatan ukuran perusahaan akan mengakibatkan peningkatan Nilai Perusahaan. Sedangkan hasil penelitian Manoppo dan Arie (2016), Purwahandoko (2017) menyatakan bahwa ukuran perusahaan tidak berpengaruh signifikan terhadap nilai perusahaan pada perusahaan. Dan menurut Widyantari dan Yadnya (2017) ukuran perusahaan berpengaruh positif dan tidak signifikan terhadap nilai perusahaan.

Mogdiliani dan Miller (1963) menyatakan nilai perusahaan ditentukan oleh struktur modal .Struktur modal (capital structure) berkaitan dengan pembelanjaan jangka panjang suatu perusahaan yang diukur dengan perbandingan hutang jangka panjang dengan modal sendiri (Sudana, 2012). Struktur modal dapat diubah-ubah agar diperoleh nilai perusahaan yang optimal (Hanafi, 2014). Menurut Musabbihan dan Purnawati (2018), Hirdinis M (2019), Uke dkk (2014) menyatakan struktur modal berpengaruh positif signifikan terhadap nilai perusahaan pada perusahaan. Sedangkan menurut Dhani dan Utama (2017) Struktur modal tidak berpengaruh terhadap nilai perusahaan. Kemudian dalam penelitian Ardi dkk (2016) menyatakan bahwa DER berpengaruh negatif signifikan terhadap PBV. Menurut Serghiescua dan Vãideanb (2014) Profitabilitas tidak berpengaruh terhadap struktur modal.Ukuran perusahaan bepengaruh positif signifikan terhadap hutang. Sedangkan menurut penelitian Dewi dan Sudiartha (2017) Profitabilitas berpengaruh positif dan signifikan terhadap struktur modal dan Ukuran perusahaan berpengaruh negatif dan tidak signifikan terhadap struktur modal. Menurut Septiani dan Suaryana (2018)
Ukuran perusahaan berpengaruh positif pada struktur modal perusahaan.

\section{Tinjauan Teori dan Pengembangan Hipotesis Profitabilitas}

Menurut Kusuma, dkk (2012) Profitabilitas (profitability) adalah kemampuan perusahaan memperoleh laba melalui operasional usahanya dengan menggunakan dana aset yang dimiliki oleh perusahaan. Profitabilitas suatu perusahaan menunjukkan perbandingan antara laba dengan aktiva atau modal yang menghasilkan laba tersebut, dengan kata lain profitabilitas adalah kemampuan perusahaan untuk menghasilkan laba selama periode tertentu (Riyanto, 2011). Rasio-rasio profitabiltas digunakan untuk mengukur seberapa jauh kemampuan perusahaan menghasilkan laba dari aset-aset yang dimilikinya atau dari ekuitas yang dimilikinya. Kemampuan suatu perusahaan dalam menghasilkan laba bisa berbeda untuk perusahaan dengan bisnis yang berbeda (Husnan dan Pudjiastuti,2018). Adapun rumus untuk menghitung ROE adalah $\mathrm{ROE}=($ Laba Setelah Pajak) / (Modal Saham) $\mathrm{x}$ $100 \%$ ..(1.1)

\section{Ukuran Perusahaan}

Ukuran perusahaan merupakan suatu penetapan besar kecilnya perusahaan. Semakin tinggi total aset yang menunjukkan harta yang dimiliki perusahaan mengindikasikan bahwa besar pula harta yang dimiliki perusahaan. Ukuran perusahaan yang diukur dengan asset perusahaan menunjukkan seberapa besar harta yang dimiliki perusahaan. Perusahaan dengan aset yang besar maka akan menggunakan sumber daya yang ada semaksimal mungkin untuk menghasilkan keuntungan usaha dan perusahaan dengan asset yang kecil tentunya juga menghasilkan keuntungan sesuai dengan aset yang dimilikinya yang relatif kecil (Rifai dkk, 2013). Menurut Riyanto (2011) Ukuran perusahaan menggambarkan besar kecilnya suatu perusahaan yang ditunjukan pada total aktiva, jumlah penjualan, rata-rata penjualan Klasifikasi ukuran perusahaan menurut UU No. 20 Tahun 2008 dibagi kedalam 4 (empat) kategori yaitu usaha mikro, usaha kecil, usaha menengah, dan usaha besar.

Menurut Jogiyanto (2013) pengukuran ukuran Ukuran perusahaan sebagai alogaritma dari total aset diprediksi mempunyai hubungan negatif dengan rasio. Kemudian perusahaan yang besar cendrung berinvestasi ke proyek yang mempunyai varian rendah, untuk menghindari laba ditahan. Menurut 
Harahap (2013) pengukuran ukuran perusahaan adalah diukur dengan logaritma natural (Ln) dari ratarata total aktiva (total asset) perusahaan. Penggunaan total aktiva berdasarkan pertimbangan bahwa total aktiva mencerminkan ukuran perusahaan dan diduga mempengaruhi ketepatan waktu. Adapun rumus perhitungan ukuran perusahaan sebagai berikut :

Ukuran Perusahaan = Logaritma Aktiva

\section{Struktur Modal}

Menurut Riyanto (2011) Struktur modal adalah pembelanjaan permanen dimana mencerminkan perimbangan antara utang jangka panjang dengan modal sendiri. Teori struktur modal konvensional (Myers, 1997; Jensen 1986) menyatakan bahwa struktur modal optimal perusahaan berhubungan dengan biaya dan manfaat yang dikaitkan dengan pendanaan utang dan ekuitas. Struktur modal adalah perimbangan antara penggunaan modal pinjaman yang terdiri dari: utang jangka pendek yang bersifat permanen, utang jangka panjang dengan modal sendiri yang terdiri dari: saham preferen dan saham biasa (Darmawan,2008). Untuk perhitungan struktur modal yang sangat berkaitan dengan pendanaan yang berasal dari modal sendiri serta penggunaan hutang, maka struktur modal dihitung dengan menggunakan debt to equity rasio (DER) adalah

DER $=($ Total Utang $) /($ Modal Sendiri $)$

\section{Nilai Perusahaan}

Husnan (2013) mendefinisikan nilai perusahaan atau juga disebut dengan nilai pasar perusahaan merupakan harga yang bersedia dibayar oleh calon pembeli apabila perusahaan tersebut dijual. Nilai perusahaan dapat dilihat melalui nilai pasar atau nilai buku perusahaan dari ekuitasnya. Nilai pasar adalah harga saham yang terjadi di pasar bursa dan ditentukan oleh pelaku pasar pada saat tertentu. Harga saham selalu mengalami perubahan setiap harinya bahkan setiap detik harga saham dapat berubah. Oleh karena itu, pelaku pasar harus mampu memperhatikan faktor-faktor yang mempengaruhi harga saham.

Menurut Gultom, dkk (2013) Nilai perusahaan merupakan sebuah nilai yang dapat digunakan untuk mengukur seberapa besar "Tingkat Kepentingan" sebuah perusahaan dilihat dari sudut pandang beberapa pihak seperti para investor yang mengaitkan nilai sebuah perusahaan dari harga sahamnya. Memaksimalkan nilai perusahaan sama dengan memaksimalkan harga saham dan itu juga yang diinginkan pemilik perusahaan karena nilai perusahaan yang tinggi mengindikasikan kemakmuran pemegang saham yang tinggi. Terdapat beberapa metode yang dapat digunakan untuk mengukur nilai perusahaan. Menurut Weston dan Copeland (2008) salah satu rasio penilaian nilai perusahaan adalah Price to Book Value (PBV) .Rasio ini menggambarkan seberapa besar pasar menghargai nilai buku saham suatu perusahaan. Semakin tinggi Price to Book value (PBV) berarti pasar percaya akan prospek perusahaan tersebut. Adapun rumus dari Price Book Value adalah

PBV $=($ Harga Saham Per Lembar $) /($ Nilai Buku Per Lembar Saham).

Berdasarkan penjelasan teoris dan studi empiris terhadap penelitian terdahulu maka pengaruh ketiga variabel tersebut terhadap nilai perusahaan peneliti mengggambarkan dalam kerangka pemikiarn sebagai berikut:

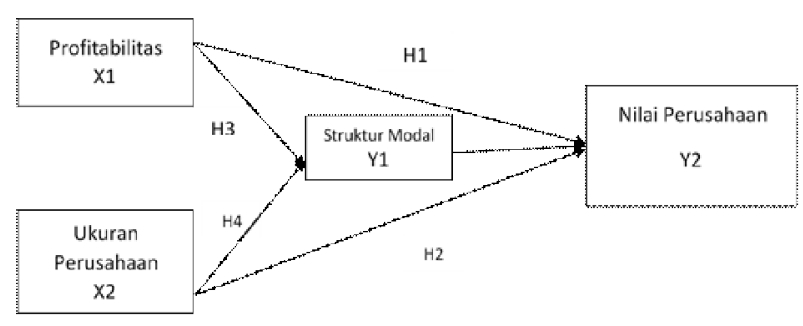

Gambar 1. Kerangka Penelitian

\section{Pengaruh Profitabilitas Terhadap Nilai Perusahaan}

Profitabilitas suatu perusahaan menunjukkan perbandingan antara laba dengan aktiva atau modal yang menghasilkan laba tersebut, dengan kata lain profitabilitas adalah kemampuan perusahaan untuk menghasilkan laba selama periode tertentu (Riyanto, 2011). Di dalam mengelola aset untuk menghasilkan profit akan berdampak terhadap penelitian nilai perusahaan.Profit yang tinggi memberikan indikasi prospek perusahaan yang baik, sehingga dapat memicu para investor untuk meningkatkan permintaan saham (Dhani \& Utama, 2017).

Menurut Sudiani dan Darmayanti (2016) profitabilitas berpengaruh positif dan signifikan terhadap nilai perusahaan sektor industri barang konsumsi di Bursa Efek Indonesia periode 2012-2014, hasil tersebut membuktikan bahwa semakin tinggi nilai profit yang didapat maka akan semakin tinggi nilai perusahaan. Berdasarkan penjelesan teori dan penelitian terdahulu diatas, maka hipotesis yang diajukan adalah sebagai berikut:

H1: Profitabilitas berpengaruh signifikan terhadap nilai Perusahaan 


\section{Pengaruh Ukuran Perusahaan Terhadap Nilai Perusahaan}

Menurut Riyanto (2011) Ukuran perusahaan menggambarkan besar kecilnya suatu perusahaan yang ditunjukan pada total aktiva, jumlah penjualan, rata-rata penjualan. Perusahaan dengan aset yang besar maka akan menggunakan sumber daya yang ada semaksimal mungkin untuk menghasilkan keuntungan usaha dan perusahaan dengan asset yang kecil tentunya juga menghasilkan keuntungan sesuai dengan aset yang dimilikinya yang relatif kecil (Rifai dkk, 2013).

Hal ini sesuai dengan penelitian Rahayu dan Sari (2018), Pramana dan Mustanda (2016) Ukuran Perusahaan secara signifikan berpengaruh positif terhadap Nilai Perusahaan. Ini berarti setiap peningkatan ukuran perusahaan akan mengakibatkan peningkatan Nilai Perusahaan. Menurut Prasetia,dkk (2014) ukuran perusahaan (Total Asset) berpengaruh positif dan signifikan terhadap nilai perusahaan (PBV). Berdasarkan penjelesan teori dan penelitian terdahulu diatas, maka hipotesis yang diajukan adalah sebagai berikut:

H2: Ukuran Perusahaan berpengaruh signifikan terhadap nilai perusahaan

\section{Pengaruh Profitabilitas Terhadap Struktur Modal}

Menurut Husnan (2018) perusahaaan yang profitable umumnya akan mempunyai rasio hutang yang rendah. Perusahaan yang tidak terlalu menguntungkan akan mempunyai rasio hutang yang tinggi, ketika mereka kekurangan pendanaan internal maka mereka akan menerbitkan hutang terlebih dahulu. Hal ini sesuai dengan penelitian Dewi dan Sudiartha (2017) bahwa profitabilitas berpengaruh positif dan signifikan terhadap struktur modal.

Menurut Wirawan (2017) profitabilitas yang konsisten membangun kepercayaan investor bahwa perusahaan tersebut sudah menggerakkan aset yang dimiliki dalam menghasilkan keuntungan. Sehingga dalam kasus ini profitabilitas berpengaruh positif dan signifikan terhadap struktur modal.Berdasarkan penjelesan teori dan penelitian terdahulu diatas, maka hipotesis yang diajukan adalah sebagai berikut:

H3 Profitabilitas berpengaruh signifikan terhadap Struktur modal

\section{Pengaruh Ukuran Perusahaan Terhadap Struktur Modal}

Menurut Husnan (2018) rasio hutang perusahaan tergantung dari beberapa faktor, salah satunya adalah ukuran perusahaan. Semakin besar ukuran perusahaan maka akan mempengaruhi struktur hutang atau rasio hutangnya juga. Hal ini sesuai dengan penelitian Septiani dan Suaryana (2018) bahwa Ukuran perusahaan berpengaruh positif pada struktur modal perusahaan. Berdasarkan penjelesan teori dan penelitian terdahulu diatas, maka hipotesis yang diajukan adalah sebagai berikut:

H4: Ukuran Perusahaan berpengaruh signifikan terhadap Struktur modal

\section{Pengaruh Struktur Modal Terhadap Nilai Perusahaan}

Struktur modal yang dapat memaksimumkan nilai perusahaan atau harga saham adalah struktur modal yang terbaik (Husnan,2018). Hal ini sesuai dengan penelitian Musabbihan dan Purnawati (2018) menyatakan struktur modal berpengaruh positif signifikan terhadap nilai perusahaan pada perusahaan. Berdasarkan penjelesan teori dan penelitian terdahulu diatas, maka hipotesis yang diajukan adalah sebagai berikut:

H5: Struktur Modal berpengaruh signifikan terhadap nilai perusahaan

\section{Struktur Modal Mampu Memediasi Profitabilitas Terhadap Nilai Perusahaan}

Modal yang dipergunakan perusahaaan selalu mempunyai biaya. Bagi dana yang berbentuk hutang, maka biaya dana mudah diidentifikasikan yaitu biaya bunga. . Penggunaan hutang dapat dibenarkan selama diharapkan dapat menghasilkan rentabilitas ekonomi (basic Earnings Power) yang lebih besar dari tingkat bunga pinjaman. Hal tersebut disebabkan karena penggunaan hutang tersebut meningkatkan rentabilitas modal sendiri (Return On Equity). Sehingga investor akan melihat jika perusahaan tersebut mempunyai nilai lebih karena ROE nya tinggi (Husnan,2018).

Menurut Dewi dan Sudiartha (2017) profitabilitas berpengaruh positif dan signifikan terhadap struktur modal dan menurut Musabbihan dan Purnawati (2018) menyatakan struktur modal berpengaruh positif signifikan terhadap nilai perusahaan pada suatu perusahaan. Berdasarkan penjelesan teori dan penelitian terdahulu diatas, maka hipotesis yang diajukan adalah sebagai berikut:

H6: Struktur Modal mampu memediasi pengaruh profitabilitas terhadap nilai perusahaan 


\section{Struktur Modal Mampu memediasi Pengaruh} Ukuran perusahaan Terhadap Nilai Perusahaan.

Jika suatu perusahaan mengganti sebagian modal sendiri dengan hutang dan dapat memaksimalkan nilai perusahaan maka akan diperoleh struktur modal yang terbaik. Sedangkan perusahaan besar cenderung mempunyai rasio hutang yang tinggi (Husnan \& Pudjiastuti, 2018)

Menurut Septiani dan Suaryana (2018) ukuran perusahaan berpengaruh positif pada struktur modal perusahaan dan menurut Musabbihan dan Purnawati (2018) menyatakan struktur modal berpengaruh positif signifikan terhadap nilai perusahaan pada suatu perusahaan. Berdasarkan penjelesan teori dan penelitian terdahulu diatas, maka hipotesis yang diajukan adalah sebagai berikut:

H7: Struktur Modal mampu memediasi pengaruh Ukuran perusahaan terhadap nilai perusahaan

\section{METODE PENELITIAN}

Desain penelitian adalah suatu strategi untuk mencapai tujuan penelitian yang telah ditetapkan dan berperan sebagai pedoman atau penuntun pada seluruh proses penelitain (Kuncoro, 2014). Jenis penelitian ini berdasarkan tingkat eksplanasi adalah penelitian yang berbentuk asosiatif, yaitu bertujuan untuk menentukan bagaimana hubungan antar variabel. Variabel yang digunakan adalah variabel independen dan variabel dependen. Pada penelitian ini, Variabel dependennya adalah nilai perusahaan, dan variabel independennya adalah profitabilitas serta ukuran perusahaan.

Unit analisis dalam penelitian ini perusahaan manufaktur sektor aneka industri yang terdaftar di Bursa Efek Indonesia yang selalu melaporkan laporan keuangan tahunan perusahaan periode tahun 20122019. Dan juga perusahaan manufaktur sektor aneka industri yang tidak pernah mengalami kerugian dalam kurun waktu tersebut. Peneliti melakukan analisis terhadap laporan keuangan perusahaan yang telah dipublikasikan dalam situs www.idx.co.id.

Operasionalisasi variabel adalah penjelasan mengenai variabel penelitian, konsep variabel, indikator variabel, ukuran variabel dan skala variabel. Operasionalisasi variabel diperlukan untuk menjabarkan variabel penelitian dan tujuan ke dalam konsep indikator yang bertujuan untuk memudahkan pengertian dan menghidari perbedaan persepsi dalam penelitian ini.
Jumlah populasi yang digunakan dalam penelitian adalah lima puluh satu perusahaan. Teknik yang digunakan dalam penelitian ini adalah purpose sampling. Menurut Ferdinand (2014) pada teknik purposive sampling peneliti memilih sampel purposif atau sampel yang bertujuan secara subyektif. Pemilihan ini dilakukan karena mungkin saja peneliti telah memahami bahwa informasi yang dibutuhkan dapat diperoleh dari satu kelompok sasaran tertentu yang mampu memberikan informasi yang dikehendaki karena mereka memang memiliki informasi dan memenuhi kriteria yang ditentukan oleh peneliti. Oleh karena itu, sampel yang dipilih sengaja ditentukan berdasarkan kriteria tertentu yang telah ditentukan oleh penulis untuk mendapatkan sampel yang representatif.

Adapun kriteria penentuan sampel dalam penelitian ini, yaitu:

1. Perusahaan Manufaktur Sektor Aneka Industri yang terdaftar secara terus menerus di BEI selama periode 2012 - 2019

2. Perusahaan Manufaktur Sektor Aneka Industri di BEI yang mempublikasikan Laporan keuangannya secara lengkap dan terus menerus selama periode 2012 - 2019

3. Perusahaan Manufaktur Sektor Aneka Industri di BEI yang tidak mengalami kerugian selama periode 2012 -2019

Sampel adalah subset dari populasi, terdiri dari beberapa anggota populasi. Subset ini diambil karena dalam banyak kasus tidak mungkin kita meneliti seluruh anggota populasi, oleh karena itu dibentuk sebuah perwakilan populasi yang disebut sampel. Dengan meneliti sampel, seorang peneliti dapat menarik kesimpulan yang dapat digeneralisasi (Ferdinand, 2014). Setelah dilakukan penentuan sampel, peneliti mendapatkan dua belas perusahaan yang dijadikan sampel dalam penelitian ini.

Jenis data dalam penelitian ini adalah data kuantitatif berupa data sekunder, yaitu dengan studi dokumen termasuk didalam nya dokumen - dokumen elektronik Sumber data diperoleh dari pengumuman data sekunder laporan keuangan tahunan yang telah dipublikasikan di Bursa Efek Indonesia. Daftar nama - nama perusahaan yang termasuk dalam Industri Otomotif pada Bursa Efek Indonesia diperoleh dari website resmi Bursa efek Indonesia, yaitu www.idx.co.id.Metode ini dipilih oleh penulis karena dalam penelitian ini bersifat time series dan cross section. Alat yang digunakan pada penelitian adalah software PLS 3.0. 


\section{HASIL DAN PEMBAHASAN}

Analisis data merupakan rangkaian penelitian yang dilakukan untuk mengetahui hasil dari pertanyaan pertanyaan peneliti. Pertanyaan penelitian memfokuskan pada mencari pengaruh variabel independen yaitu profitabilitas, ukuran perusahaaan dan struktur modal terhadap variabel dependen yaitu nilai perusahaan .

\section{Evaluasi Measurement (Outer) Model}

Convergent validity dari measurement model dengan indikator refleksif dapat dilihat dari korelasi antara score item/indikator dengan score konstruknya. Indikator individu dianggap reliabel jika memiliki nilai korelasi di atas 0,70 . Namun demikian pada riset tahap pengembangan skala, loading 0,50 sampai 0,60 masih dapat diterima. Berdasarkan pada result for outer loading maka seluruh indikator memiliki loading di atas 0,50 dan signifikan.

Pengujian validitas untuk indikator reflektif menggunakan korelasi antara skor item dengan skor konstruknya. Pengukuran dengan indikator reflektif menunjukkan adanya perubahan pada suatu indikator dalam suatu konstruk jika indikator lain pada konstruk yang sama berubah (atau dikeluarkan dari model). Indikator reflektif cocok digunakan untuk mengukur persepsi sehingga penelitian ini menggunakan indikator reflektif. Berdasarkan hasil analisis dari Tabel di atas diketahui bahwa seluruh dimensi telah memenuhi convergent validity karena memiliki nilai loading lebih dari 0.50 .

Discriminat validity dari model pengukuran dengan indikator refleksif dinilai berdasarkan cross loading pengukuran dengan konstruk. Jika korelasi konstruk dengan item pengukuran lebih besar daripada ukuran konstruk lainnya, maka hal itu menunjukkan bahwa konstruk laten memprediksi ukuran pada blok mereka lebih baik daripada ukuran pada blok lainnya. Cara lain mengukur discriminat validity adalah melihat nilai square root of average variance extracted (AVE). Nilai yang disarankan adalah di atas 0,5. Untuk semua konstruk, yaitu Nilai Perusahaan, Profitabilitas, Struktur Modal dan Ukuran Perusahaan memiliki nilai AVE yang sama yakni sebesar 1.000. Hasil ini berarti semua konstruk memiliki discriminat validity yang tinggi.

Pengujian selanjutnya adalah Composite Reliability dari blok indikator yang mengukur konstruk. Suatu konstruk dikatakan reliable jika nilai Composite Reliability di atas 0,60. Hasil dari composite reliablity yaitu Nilai Perusahaan,
Profitabilitas, Struktur Modal dan Ukuran Perusahaan yang memiliki nilai composite reliablity yang sama yakni sebesar 1.000. Hasil ini berarti semua variabel yang digunakan dalam penelitian ini reliabel.

\section{Evaluasi Model Struktural atau Inner Model}

Menilai inner model adalah mengevaluasi hubungan antar konstruk laten seperti yang telah dihipotesiskan dalam penelitian ini, yaitu bagaimana hubungan model pertama menguji pengaruh Profitabilitas dan Ukuran Perusahaan terhadap Nilai Perusahaan dengan Struktur Modal sebagai intervening. R square yang terbentuk dari dua model tersebut adalah sebagai berikut:

Tabel 1.

Hasil R-Square

\begin{tabular}{|l|r|}
\hline \multicolumn{1}{|c|}{ Model } & R Square \\
\hline Nilai Perusahaan & $\mathbf{0 . 6 0 6}$ \\
\hline Struktur Modal & $\mathbf{0 . 8 3 1}$ \\
\hline
\end{tabular}

Sumber: Data diolah (2020)

Berdasarkan tabel di atas dapat dijelaskan bahwa pada model pertama menunjukkan bahwa variabel Profitabilitas dan Ukuran Perusahaan melalui Struktur Modal mampu menjelaskan variabilitas konstruk Nilai Perusahaan sebesar 0.606 atau 60,6 persen dan sisanya sebesar 39,4 persen diterangkan oleh konstruk lainnya diluar variabel yang diteliti dalam penelitian ini. Sedangkan pada model kedua menunjukkan Profitabilitas dan Ukuran Perusahaan mampu menjelaskan variabilitas konstruk Struktur Modal sebesar 0.831 atau 83,1 persen dan sisanya sebesar 16,9 persen diterangkan oleh konstruk lainnya diluar variabel yang diteliti dalam penelitian ini.

\section{Pengujian Model Struktural (Inner Model)}

Pengujian model struktural dalam analisis Partial Least Square (PLS) dikenal dengan uji goodness of fit model berupa nilai predictive relevance (Q2). Nilai predictive relevance (Q2) mengukur seberapa baik nilai observasi dihasilkan oleh model dan juga estimasi parameternya. Nilai ini dihitung berdasarkan nilai koefisien determinasi (R2) variabel laten dependen dengan interpretasi yang sama dengan regresi. Nilai Q-Square > 0 menunjukkan model memiliki predictive relevance, sebaliknya jika nilai Q-Square d" 0 menunjukkan model kurang memiliki predictive relevance. Berdasarkan tabel 4.6, untuk menguji kelayakan model dilakukan dengan 
menggunakan nilai $Q$-square predictive-relevance (Q2). Adapun formula dan hasil perhitungan Qsquare sebagai berikut:

$\mathrm{Q} 2=1-(1-\mathrm{R} 12)(1-\mathrm{R} 22)$

$\mathrm{Q} 2=1-(1-0.606)(1-0.831)$

$\mathrm{Q} 2=0.804=80,4 \%$

Hasil perhitungan menunjukan nilai $Q$-square predictive-relevance $(\mathrm{Q} 2)$ sebesar 80,4 persen. Nilai $Q$-square predictive-relevance (Q2) sebesar 80,4 persen tersebut mengindikasikan bahwa model yang dibangun adalah baik karena mempunyai daya kemampuan predictive relevance sebesar 80,4 persen. Dengan demikian model yang telah dibangun layak digunakan untuk pengujian hipotesis.

\section{Uji Pengaruh Langsung}

Hasil analisis jalur digunakan untuk melihat pengaruh antar variabel dengan melihat taraf signifikasi antar variabel, serta hubungan antar variabel. Berikut adalah ringkasan hipotesis penelitian yang telah penulis rinci sebagai tabel:

Tabel 2. Uji Pengaruh Langsung

\begin{tabular}{|l|r|r|r|r|r|}
\hline \multicolumn{1}{|c|}{ Hipotesis } & Original Sample & Sample Mean & Standar Deviasi & \multicolumn{1}{c|}{ T $_{\text {Statistik }}$} & \multicolumn{1}{c|}{ P Value } \\
\hline 1. Profitabilitas -> Nilai Perusahaan & 0.567 & 0.567 & 0.070 & 8.092 & 0.000 \\
\hline 3. Profitabilitas -> Struktur Modal & -0.352 & -0.347 & 0.063 & 5.614 & 0.000 \\
\hline 5. Struktur Modal -> Nilai Perusahaan & -0.191 & -0.193 & 0.062 & 3.101 & 0.002 \\
\hline 2. Ukuran Perusahaan -> Nilai Perusahaan & 0.292 & 0.287 & 0.073 & 4.025 & 0.000 \\
\hline 4. Ukuran Perusahaan -> Struktur Modal & -0.069 & -0.068 & 0.049 & $\mathbf{1 . 4 0 5}$ & $\mathbf{0 . 1 6 1}$ \\
\hline
\end{tabular}

Sumber: Data diolah (2020)

1. Pengaruh Profitabilitas terhadap Nilai Perusahaan

Pada hipotesis pertama yang menguji pengaruh Profitabilitas terhadap Nilai Perusahaan, diketahui hasil perhitungan statistik menunjukkan thitung sebesar 8,092, nilai p-value sebesar 0.000 dan koefisien jalur (beta) atau original sample 0.567 . Hasil uji t menggambar bahwa nilai thitung lebih besar dari ttabel $(8,092$ $>1,96)$, sedang berdasarkan hasil $\mathrm{p}$-value perhitungan menunjukkan bahwa p-value lebih kecil dari nilai á $(0,000<0,05)$ maka dapat dikatakan bahwa profitabilits berpengaruh signifikan terhadap nilai perusahaan.

2. Pengaruh Profitabilitas terhadap Struktur Modal Pada hipotesis kedua yang menguji pengaruh Profitabilitas terhadap Struktur Modal, diketahui hasil perhitungan statistik menunjukkan thitung sebesar 5.614, nilai p-value sebesar 0.000 dan koefisien jalur (beta) atau original sample -0.352 . Hasil uji t menggambar bahwa nilai thitung lebih besar dari ttabel $(5.614>1,96)$, sedang berdasarkan hasil p-value perhitungan menunjukkan bahwa p-value lebih kecil dari nilai á $(0,000<0,05)$ maka dapat dikatakan hasil pengujian menunjukkan bahwa profitabilitas berpengaruh signifikan terhadap struktur modal. Selanjutnya nilai koefisien jalur (beta) memiliki angka negatif, maka pengaruhnya signifikan negatif.

3. Pengaruh Struktur Modal terhadap Nilai Perusahaan

Pada hipotesis ketiga yang menguji pengaruh Struktur Modal terhadap Nilai Perusahaan, diketahui hasil perhitungan statistik menunjukkan thitung sebesar 3.101, nilai p-value sebesar 0.002 dan koefisien jalur (beta) atau original sample -0.191 . Hasil uji t menggambar bahwa nilai thitung lebih besar dari ttabel $(3,101$ $>1,96)$, sedang berdasarkan hasil p-value perhitungan menunjukkan bahwa p-value lebih kecil dari nilai á $(0,002<0,05)$ maka dapat dikatakan hasil pengujian menunjukkan bahwa struktur modal berpengaruh signifikan terhadap nilai perusahaan. Selanjutnya nilai koefisien jalur (beta) memiliki angka negatif, maka pengaruhnya signifikan dan negatif.

4. Pengaruh Ukuran Perusahaan terhadap Nilai Perusahaan

Pada hipotesis keempat yang menguji pengaruh Ukuran Perusahaan terhadap Nilai Perusahaan, diketahui hasil perhitungan statistik menunjukkan thitung sebesar 4.025 , nilai p-value sebesar 0.000 dan koefisien jalur (beta) atau original sample 0.292. Hasil uji t menggambar bahwa nilai thitung lebih besar dari ttabel $(4,025$ $>1,96)$, sedang berdasarkan hasil p-value perhitungan menunjukkan bahwa p-value lebih 
kecil dari nilai á $(0,000<0,05)$ maka dapat dikatakan hasil pengujian menunjukkan bahwa ukuran perusahaan berpengaruh signifikan terhadap nilai perusahaan. Selanjutnya nilai koefisien jalur (beta) memiliki angka positif, maka pengaruhnya signifikan dan positif..

5. Pengaruh Ukuran Perusahaan terhadap Struktur Modal

Pada hipotesis kelima yang menguji pengaruh Ukuran Perusahaan terhadap Struktur Modal, diketahui hasil perhitungan statistik menunjukkan thitung sebesar 1.405 , nilai p-value sebesar 0.161 dan koefisien jalur (beta) atau original sample -0.069 . Hasil uji t menggambar bahwa nilai thitung lebih kecil dari ttabel (1.405 $<1,96)$, sedang berdasarkan hasil p-value perhitungan menunjukkan bahwa p-value lebih besar dari nilai á $(0.161>0,05)$ maka dapat dikatakan hasil pengujian menunjukkan bahwa ukuran perusahaan berpengaruh tidak berpengaruh terhadap struktur modal.

\section{Pengujian Hipotesis Indirect}

Berikut adalah hasil analisis untuk melihat pengaruh tidak langsung dari variabel profitabilitas melalui struktur modal terhadap nilai perusahaan dan pengaruh tidak langsung dari variabel ukuran perusahaan melalui struktur modal terhadap nilai perusahaan

Tabel 3.

Uji Pengaruh Tidak Langsung

\begin{tabular}{|l|r|r|r|r|r|}
\hline \multicolumn{1}{|c|}{ Hipotesis } & \multicolumn{1}{|c|}{$\begin{array}{c}\text { Original } \\
\text { Sample }\end{array}$} & $\begin{array}{c}\text { Sample } \\
\text { Mean }\end{array}$ & $\begin{array}{c}\text { Standar } \\
\text { Deviasi }\end{array}$ & $\mathbf{T}_{\text {Statistik }}$ & P Value \\
\hline $\begin{array}{l}\text { Profitabilitas -> Struktur } \\
\text { Modal -> Nilai Perusahaan }\end{array}$ & 0.067 & 0.067 & 0.026 & 2.571 & 0.010 \\
\hline $\begin{array}{l}\text { Ukuran Perusahaan -> } \\
\text { Struktur Modal -> Nilai } \\
\text { Perusahaan }\end{array}$ & 0.013 & 0.014 & 0.012 & 1.099 & 0.272 \\
\hline
\end{tabular}

Sumber : Diolah peneliti 2020

6. Pengaruh Profitabilitas terhadap Nilai Perusahaan melalui Struktur Modal

Pada hipotesis keenam yang menguji pengaruh tidak langsung Profitabilitas terhadap Nilai Perusahaan melalui Struktur Modal, diketahui hasil perhitungan statistik menunjukkan thitung sebesar 2.571, nilai p-value sebesar 0.010 dan koefisien jalur (beta) atau original sample 0.067 . Hasil uji t menggambar bahwa nilai thitung lebih besar dari ttabel $(2.571>1,96)$, sedang berdasarkan hasil p-value perhitungan menunjukkan bahwa p-value lebih kecil dari nilai á $(0,010<0,05)$ maka dapat dikatakan hasil pengujian menunjukkan bahwa profitabilitas melalui struktur modal berpengaruh signifikan terhadap nilai perusahaan. Selanjutnya nilai koefisien jalur (beta) memiliki angka positif, maka pengaruhnya signifikan dan positif. Hasil ini dapat diartikan bahwa Struktur Modal mampu memediasi pengaruh profitabilitas terhadap Nilai Perusahaan.

7. Pengaruh Ukuran Perusahaan terhadap Nilai Perusahaan melalui Struktur Modal

Pada hipotesis ketujuh yang menguji pengaruh tidak langsung Ukuran Perusahaan terhadap Nilai Perusahaan melalui Struktur Modal, diketahui hasil perhitungan statistik menunjukkan thitung sebesar 1.099, nilai p-value sebesar 0.272 dan koefisien jalur (beta) atau original sample 0.013 . Hasil uji t menggambar bahwa nilai thitung lebih kecil dari ttabel (1.099 $<1,96$ ), sedang berdasarkan hasil p-value perhitungan menunjukkan bahwa p-value lebih besar dari nilai á $(0.272>0,05)$ maka dapat dikatakan bahwa ukuran perusahaan melalui struktur modal berpengaruh tidak signifikan. Selanjutnya nilai koefisien jalur (beta) memiliki angka positif, maka pengaruhnya tidak signifikan dan positif. Hasil ini dapat diartikan bahwa Struktur Modal tidak mampu memediasi pengaruh Ukuran Perusahaan terhadap Nilai Perusahaan.

\section{PEMBAHASAN}

Pengaruh Profitabilitas Terhadap Nilai Perusahaan Hasil penelitian menunjukan bahwa Profitabilitas berpengaruh positif dan signifikan terhadap Nilai Perusahaan.Hal tersebut dikarenakan setiap peningkatan profitabilitas pada perusahaan maka nilai perusahaannya pun semakin meningkat. Didukung juga pada 12 sampel perusahaan banyak perusahaan yang mempunyai rasio profitabilitas nya tinggi, seperti ASII, AUTO, BRAM ,JECC, KBLI.

Menurut Kusuma, dkk (2012) Profitabilitas (profitability) adalah kemampuan perusahaan memperoleh laba melalui operasional usahanya dengan menggunakan dana aset yang dimiliki oleh perusahaan. Perusahaan dengan profit yang tinggi maka akan membuat nilai perusahaan tersebut menjadi tinggi juga dimata investor. Menurut Dhani dan Utama (2017) dalam mengelola aset untuk menghasilkan profit akan berdampak terhadap penelitian nilai perusahaan. Profit yang tinggi memberikan indikasi prospek perusahaan yang baik, sehingga dapat memicu para investor untuk meningkatkan permintaan saham. 
Hasil penelitian ini sesuai dengan beberapa hasil penelitian sebelumnya bahwa Profitabilitas perusahaan berhubungan positif dan signifikan terhadap nilai perusahaan. Penelitian Sudiani dan Darmayanti (2016) menunjukkan profitabilitas berpengaruh positif dan signifikan terhadap nilai perusahaan sektor industri barang konsumsi di Bursa Efek Indonesia periode 2012-2014, hasil tersebut membuktikan bahwa semakin tinggi nilai profit yang didapat maka akan semakin tinggi nilai perusahaan. Penelitian Anung dkk (2017) juga menunjukkan Profitabillitas berpengaruh signifikan terhadap Nilai Perusahaan pada perusahaan pertambangan yang terdaftar di BEI tahun 2012-2019. Dengan demikian hipotesis yang diajukan peneliti yang menyatakan bahwa profitablitas berpengaruh terhadap nilai perusahaan dinyatakan terbukti.

\section{Pengaruh Ukuran Perusahaan Terhadap Nilai Perusahaan}

Hasil penelitian menunjukan bahwa Ukuran Perusahaan berpengaruh signifikan dan positif terhadap Nilai Perusahaan. Hal ini dikarenakan hampir seluruh sampel penlitian memiliki rasio dari ukuran perusahaan yang cukup tinggi. Ukuran perusahaan merupakan suatu penetapan besar kecilnya perusahaan. Ukuran perusahaan menggambarkan besar kecilnya suatu perusahaan yang ditunjukan pada total aktiva, jumlah penjualan, rata-rata penjualan (Riyanto, 2011). Perusahaan dengan aset yang besar maka akan menggunakan sumber daya yang ada semaksimal mungkin untuk menghasilkan keuntungan usaha dan perusahaan dengan asset yang kecil tentunya juga menghasilkan keuntungan sesuai dengan aset yang dimilikinya yang relatif kecil (Rifai dkk, 2013).

Hasil penelitian ini sesuai dengan beberapa hasil penelitian sebelumnya salah satunya penelitian oleh Rahayu dan Sari (2018), Pramana dan Mustanda (2016) yang menunjukkan hasil penelitian bahwa Ukuran Perusahaan secara signifikan berpengaruh positif terhadap Nilai Perusahaan. Ini berarti setiap peningkatan ukuran perusahaan akan mengakibatkan peningkatan Nilai Perusahaan. Selain itu penelitian Prasetia,dkk (2014) juga menemukan bahwa ukuran perusahaan (Total Asset) berpengaruh positif dan signifikan terhadap nilai perusahaan (PBV). Dengan demikian hipotesis yang diajukan peneliti yang menyatakan bahwa ukuran perusahaan berpengaruh terhadap nilai perusahaan dinyatakan terbukti.

\section{Pengaruh Profitabilitas Terhadap Struktur Modal}

Hasil penelitian menunjukan bahwa Profitabilitas berpengaruh signifikan dan negatif terhadap Struktur Modal. Pengaruh negatif yang diberikan dapat diartikan bahwa semakin tinggi keuntungan yang diperoleh perusahaan menjadikan kebutuhan dana khususnya dari investor baik dalam jangka pendek maupun panjangnya makin kecil.

Profitabilitas suatu perusahaan menunjukkan perbandingan antara laba dengan aktiva atau modal yang menghasilkan laba tersebut, dengan kata lain profitabilitas adalah kemampuan perusahaan untuk menghasilkan laba selama periode tertentu (Riyanto, 2011). Perusahaan dengan tingkat profitabilitas yang tinggi cenderung menggunakan dana internal untuk keperluan operasi maupun investasinya. Perusahaan dengan tingkat keuntungan yang lebih besar memiliki sumber pendanaan internal yang lebih besar dan memiliki kebutuhan untuk melakukan pembiayaan investasi melalui pendanaan external yang lebih kecil karena tingkat pengembalian yang tinggi kebutuhan dana dapat diperoleh dari laba ditahan.

Hasil penelitian ini sesuai dengan beberapa hasil penelitian sebelumnya bahwa Profitabilitas perusahaan berpengaruh terhadap Struktur Modal. Salah satunya penelitian oleh Menurut Serghiescua dan Vãideanb (2014) Profitabilitas tidak berpengaruh terhadap struktur modal. Sedangkan penelitian Dewi dan Sudiartha (2017) justru menemukan bahwa profitabilitas berpengaruh positif dan signifikan terhadap struktur modal. Dengan demikian hipotesis yang diajukan peneliti yang menyatakan bahwa profitabilitas berpengaruh terhadap struktur modal dinyatakan terbukti.

\section{Pengaruh Ukuran Perusahaan Terhadap Struktur Modal}

Hasil penelitian menunjukan bahwa Ukuran Perusahaan tidak berpengaruh dan negatif terhadap Struktur Modal. Hasil ini dapat diartikan bahwa ukuran perusahaan yang besar tidak menjamin kelangsungan hidup perusahaan maupun lancarnya kegiatan operasional perusahaan, dengan demikian ukuran perusahaan tidak menjamin minat investor maupun kreditor dalam menanamkan dananya ke perusahaan.

Ukuran perusahaan merupakan suatu penetapan besar kecilnya perusahaan. Ukuran perusahaan menggambarkan besar kecilnya suatu perusahaan 
yang ditunjukan pada total aktiva, jumlah penjualan, rata-rata penjualan (Riyanto, 2011). Ukuran perusahaan sangat bergantung pada besar kecilnya perusahan terutama berkaitan dengan kemampuan memperoleh pinjaman. Perusahaan besar lebih mudah memperoleh pinjaman karena nilai aktiva yang dijadikan jaminan lebih besar dan tingkat kepercayaan bank atau lembaga keuangan jauh lebihtinggi.

Hasil penelitian ini tidak sesuai dengan penelitian Septiani dan Suaryana (2018) yang menemukan hasil bahwa Ukuran perusahaan berpengaruh positif pada struktur modal perusahaan. Sedangkan hasil penelitian ini sesuai dengan beberapa hasil penelitian sebelumnya salah satunya adalah penelitian oleh Dewi dan Sudiartha (2017) yang menemukan bahwa ukuran perusahaan tidak berpengaruh signifikan terhadap struktur modal. Dengan demikian hipotesis yang diajukan peneliti yang menyatakan bahwa ukuran perusahaan berpengaruh terhadap struktur modal dinyatakan tidak terbukti.

\section{Pengaruh Struktur Modal Terhadap Nilai Perusahaan}

Hasil penelitian menunjukan bahwa Struktur Modal berpengaruh negatif signifikan terhadap Nilai Perusahaan. Hal ini menjelaskan bahwa semakin besar Struktur Modal yang dimiliki perusahaan yang diidentifikasikan dengan nilai hutang yang besar tidak berpengaruh pada penurunan Nilai Perusahaan.

Menurut Riyanto (2011) Struktur modal adalah pembelanjaan permanen dimana mencerminkan perimbangan antara utang jangka panjang dengan modal sendiri. Struktur modal yang dapat memaksimumkan nilai perusahaan atau harga saham adalah struktur modal yang terbaik (Husnan, 2018). Perusahaan yang dapat memperoleh hutang dari pihak luar adalah perusahaan yang dipercaya memiliki kemampuan. Selain itu struktur modal yang lebih menekankan pada hutang mencerminkan bahwa perusahaan berada dalam kondisi pertumbuhan yang mana perusahaan dalam kondisi membutuhkan pendanaan yang besar untuk berbagai investasinya.

Hasil penelitian ini sesuai dengan beberapa hasil penelitian sebelumnya salah satunya penelitian oleh Dhani dan Utama (2017)) yang menunjukkan bahwa struktur modal yang diukur dengan DER tidak memiliki pengaruh yang signifikan terhadap Nilai Perusahaan yang diukur dengan PBV. Penelitian oleh Musabbihan dan Purnawati (2018) juga menyatakan struktur modal berpengaruh positif signifikan terhadap nilai perusahaan pada perusahaan. Dengan demikian hipotesis yang diajukan peneliti yang menyatakan bahwa struktur modal berpengaruh terhadap struktur modal dinyatakan terbukti.

Pengaruh Profitabilitas terhadap Nilai Perusahaan melalui Struktur Modal

Hasil penelitian menunjukan bahwa Struktur Modal mampu memediasi pengaruh profitabilitas terhadap Nilai Perusahaan. Hal ini disebakan sampel penelitian mempunyai pengelolaan hutang yang baik. Modal yang dipergunakan perusahaaan selalu mempunyai biaya. Bagi dana yang berbentuk hutang, maka biaya dana mudah diidentifikasikan yaitu biaya bunga. . Penggunaan hutang dapat dibenarkan selama diharapkan dapat menghasilkan rentabilitas ekonomi (basic Earnings Power) yang lebih besar dari tingkat bunga pinjaman. Hal tersebut disebabkan karena penggunaan hutang tersebut meningkatkan rentabilitas modal sendiri (Return On Equity). Sehingga investor akan melihat jika perusahaan tersebut mempunyai nilai lebih karena ROE nya tinggi (Husnan, 2018). Hasil penelitian ini sejalan dengan penelitian Siswanti, dkk (2015) yang menyatakan bahwa profiatbilitas berpengaruh signifikan terhadap nilai perusahaan. Dengan demikian hipotesis yang diajukan peneliti yang menyatakan bahwa struktur modal mampu memediasi profitabiltas terhadap nilai perusahaan dinyatakan terbukti.

Pengaruh Ukuran Perusahaan terhadap Nilai Perusahaan melalui Struktur Modal

Hasil penelitian menunjukan bahwa Struktur Modal tidak mampu memediasi pengaruh Ukuran Perusahaan terhadap Nilai Perusahaan. Hal ini disebabkan karena ukuran perusahaan tidak berpengaruh terhadap struktur modal.

Ukuran perusahaan merupakan suatu penetapan besar kecilnya perusahaan. Ukuran perusahaan menggambarkan besar kecilnya suatu perusahaan yang ditunjukan pada total aktiva, jumlah penjualan, rata-rata penjualan (Riyanto, 2011). Jika suatu perusahaan mengganti sebagian modal sendiri dengan hutang dan dapat memaksimalkan nilai perusahaan maka akan diperoleh struktur modal yang terbaik. Sedangkan perusahaan besar cenderung mempunyai rasio hutang yang tinggi (Husnan \& Pudjiastuti, 2018). Dengan demikian hipotesis yang diajukan peneliti yang menyatakan bahwa struktur modal mampu memediasi ukuran perusahaan terhadap nilai perusahaan dinyatakan tidak terbukti. 


\section{KESIMPULAN}

Berdasarkan hasil analisis yang telah dijabarkan, maka dapat disimpulkan bahwa Profitabilitas, Ukuran Perusahaan dan Struktur Modal berpengaruh terhadap Nilai Perusahaan Profitabilitas berpengaruh signifikan dan negatif terhadap Struktur Modal, Ukuran Perusahaan tidak berpengaruh tidak dan negatif terhadap Struktur Modal, sehingga Struktur Modal mampu memediasi pengaruh profitabilitas terhadap Nilai Perusahaan. Sedangakn disisi lain Struktur Modal tidak mampu memediasi pengaruh Ukuran Perusahaan terhadap Nilai Perusahaan.

\section{Saran}

Untuk perusahaan baik yang menjadi subjek dalam penelitian ini mauapun diluar peneltiian idapat lebih memperhatikan beberapa faktor terkait dalam penelitian ini untuk mengoptimalkan nilai perusahaan. Untuk investor diharapkan penelitian ini dapat menjadi acuan dalam membuat keputusan.

\section{DAFTAR PUSTAKA}

Anton, Sorin Gabriel.2016.The Impact Of Dividend Policy On Firm Value. A Panel Data Analysis Of Romanian Listed Firms. Journal of Public Administration, Finance and Law

Anung dkk .2017.Pengaruh Profitabilitas, Ukuran Perusahaan terhadap Nilai Perusahaan dengan variable Struktur modal sebagai variable interveing pada perusahaan pertambangan yang terdaftar di BEI thn 2012-2016 Ekonomi Akuntansi 2017

Ardi Paminto, Djoko Setyadi dan Jhonny Sinaga.2016.The Effect of Capital Structure, Firm Growth and Dividend Policy on Profitability and Firm Value of the Oil Palm Plantation Companies in Indonesia European Journal of Business and Management www.iiste.org ISSN 2222-1905 (Paper) ISSN 2222-2839 (Online) Vol.8, No.33, 2016

Brigham \& Houston .2011.Dasar-Dasar Manajemen Keuangan.Buku 2 Edisi 11.Jakarta: Salemba Empat.

Chin, W. W. 1998. The Partial Least Squares Approach for Structural equation modeling.in G.A. Marcoulides(Ed), Modern methods for business research (pp.295236).London: Lawrence Erlbaum Associates.

Dermawan Sjahrial. 2008. Manajemen Keuangan. Edis 2. Penerbit Mitra Wacana Media. Jakarta
Dewi, Dewa Ayu Intan Yoga Maha dan Gede Mertha Sudiartha.2017. Pengaruh profitabilitas, ukuran perusahaan, dan Pertumbuhan aset terhadap struktur modal dan nilai Perusahaan. E-Jurnal Manajemen Unud, Vol. 6, No. 4, 2017: 22222252 ISSN : 2302-8912

Dhani, Isabella dan A.A Gde utama .2017.Pengaruh Pertumbuhan Perusahaan, Struktur Modal dan Profitabilitas Terhadap Nilai Perusahaan.Jurnal Riset Akuntansi dan Bisnis Airlangga Vol.2 No.1

Eisenhardt, Kathleem. M. 1989. Agency Theory: An Assesment And Review. Academy of Management Review, 14,57-74

Ferdinan,A. (2014). Metode Penelitian Manajemen: Pedoman Penelitian Untuk Penulisan Skripsi,Tesis, dan Disertasi Ilmu Manajemen. Semarang:UNDIP Press.

Ghozali, imam dan Hengky Latan.2015. Partial Least Squares: Konsep, Teknik dan Aplikasi menggunakan program SmartPLS 3.0 untuk penelitian Empiris.Universitas Diponegoro Semarang. ISBN:979.704.300.2

Gultom, Robinot. dkk .2013. Analisis Faktor-Faktor Yang Mempengaruhi Nilai Perusahaan Pada Perusahaan Farmasi Di Bursa Efek Indonesia. Jurnal Wira Ekonomi Mikroskil Volume 3, Nomor 01

Hanafi, Mamduh M., 2014. Manajemen Keuangan. Edisi Pertama. Yogyakarta: BPFE

Harahap, Sofyan Safri. 2013. Analisis Kritis Atas Laporan Keuangan. Jakarta: PT Rajawali Pers.

Husna, Suad dan Enny Pudjiastuti. 2018. Dasardasar Manajemen : Buku Edisi Ketujuh. .Yogyakarta : UPP STIM YKPN

Husnan, Suad. 2000. Manajemen Keuangan Teori dan Penerapan (Keputusan Jangka Panjang), Buku 1, Edisi Keempat. Yogyakarta:BPFE.

Husnan, Suad. 2013. Manajemen Keuangan Edisi Keempat. BPFE, Yogyakarta

Jensen, M. C. And Meckling, W. H. 1976. Theory of the Firm: Managerial Behavior, Agency Costs and Capital Structure.Journal of Financial Economics, 3, 11-25

Jogiyanto. 2013. Analisis \& Desain Sistem Informasi : Pendekatan tertruktur teoridan praktik aplikasi bisnis.Andi Offset. Yogyakarta 
Kusuma, Indra Gunawan dkk .2012. Analisis Pengaruh Profitabilitas (Profitability) Dan Tingkat Pertumbuhan (Growth) Terhadap Struktur Modal Dan Nilai Perusahaan (Studi pada Perusahaan Real Estate and Property yang Terdaftar di Bursa Efek Indonesia (BEI) Periode 2007-2011).

M. Hirdinis.2019.Capital Structure and Firm Size on Firm Value Moderated by Profitability. International Journal of Economics and Business Administration Volume VII, Issue 1, 2019 pp. 174-191

Manopo,Heven \& Fitty Valdi Arie .2016.Pengaruh Struktur Modal, Ukuran Perusahaan dan Profitabilitas terhadap Nilai Perusahaan otomotif yang terdaftar di BEI Periode 2011 - 2014. Jurnal EMBA Vol.4 No.2

Modigliani, F., dan M. H. Miller. 1963. Corporate Income Taxes and The Cost of Capital: A Correction. The American Economic Review 53 (3): 433-443.

Musabbihan,NellyAgustina dan Ni Ketut Purnawati.2018. Pengaruh profitabilitas dan kebijakan dividenTerhadap nilai perusahaan dengan struktur modal Sebagai pemediasi.EJurnal Manajemen Unud, Vol. 7, No. 4, 2018: 1979-2009 ISSN : 2302-8912 DOI:https:// doi.org/10.24843/EJMUNUD.2018.v7.i04.p10

Myers, S. C.,. 1977. Determinants of Corporate Borrowing, Joumal of Financial Ecollomics, No.5, 147-175.[55].

Niresh, J. Aloy dan T. Velnampy. 2014. Firm Size and pritability: A Study of Listed Manufacturing Firms in Sri Lanka. International Journal of Business and Management, 9 (4), pp: 57-64

Pramana,I Gusti Ngurah Agung Dwi dan I Ketut Mustanda.2016, Pengaruh Profitabilitas Dan Size Terhadap Nilai Perusahaan Dengan Csr Sebagai Variabel Pemoderasi. E-Jurnal Manajemen Unud, Vol. 5, No.1, 2016: 561 594 ISSN: 2302-8912.

Prasetia, Ta'dir Eko,Parengkuan Tommy dan Ivone S. Saerang .2014. Struktur modal, ukuran perusahaan dan risiko perusahaan terhadap Nilai perusahaan otomotif yang terdaftar di bei. Jurnal EMBA 879

Purwahandoko.2017. The Influence of Firm's Size, Growth, and Profitability on Firm Value with Capital Structure as the Mediator: A Study on the Agricultural Firms Listed in the Indonesian Stock Exchange. International Journal of Economics and Finance; Vol. 9, No. 8; 2017
ISSN 1916-971X E-ISSN 1916-9728 Published by Canadian Center of Science and Education

Rahayu, Maryati dan Bida Sari. 2018. Faktor-Faktor Yang Mempengaruhi Nilai Perusahaan. Univesitas Persada YAI Ikraith-Humaniora Vol. 2, No. 2.

Rifai Moch, Arifati Rina, dan Magdalena Maria. 2015. Pengaruh Ukuran Perusahaan,Struktur Modal dan Pertumbuhan Perusahaan terhadap Profitabilitas Studi pada Perusahaan manufaktur di BEI tahun 2010-2012.

Riyanto, Bambang. 2011. Dasar-dasar Pembelanjaan Perusahaan. Edisi ke 4. Yogyakarta: Yayasan Penerbit Gajah Mada

Sabrin, Buyung Sarita, Dedy Takdir .S, Sujono .2016..The Effect of Profitability on Firm Value in Manufacturing Company at Indonesia Stock Exchange.The International Journal of Engineering And Science (IJES)

Sekaran,U \& Bougie. 2013. Edisi 5, Research Metods For Business: A Skill - building Approach. New York: Jhon Wiley \& Sons,Inc

Septiani,Ni Putu Nita dan I Gusti Ngurah Agung Suaryana .2018. Pengaruh Profitabilitas, Ukuran Perusahaan, Struktur Aset, Risiko Bisnis dan Likuiditas pada Struktur Modal EJurnalAkuntansi Universitas Udayana Vol.22.3.Maret(2018):1682-1710 DOI:https:// doi.org/10.24843/EJA.2018.v22.i03.p02

Serghiescua,Laura \& Viorela-Ligia Vãideanb .2014. Determinant factors of the capital structure of a firm- an empirical analysis. Elsevier Procedia Economics and Finance 15 ( 2014 ) 1447 1457

Siswanti,I., Sukoharsono, E,G., \& Prowanta,E. (2015). The Impact of Macro Economics on Firm Values and Financial Performance as an Intervening Variable: An Empirical Study of LQ45 Banking Industries in Indonesia. Global Journal of Business and Social Science Review. Vol. 3(1); 88-94.

Sudana, I Made.,. 2012. Manajemen Keuangan Perusahaan Teori dan Praktik, Jakarta:Erlangga

Sudiani,Ni Kadek Ayu dan Ni Putu Ayu Darmayanti, 2016, Pengaruh Profitabilitas, Likuiditas, Pertumbuhan, Dan Investment Opportunity Set Terhadap Nilai Perusahaan. E-Jurnal Manajemen Unud, Vol. 5, No.7, 2016: 45454547 ISSN : 2302-8912. 
Thaib ilham, Acong Dewantoro .2017. Pengaruh Profitabilitas dan Likuiditas Terhadap Nilai Perusahaan dengan Struktur Modal sebagai Variabel Intervening (Studi pada Perusahaan Transportasi Laut Di Bursa Efek Indonesia. Jurnal Riset Perbankan Manajemen \& Akuntansi Vol.1 No.1 2017

Uke Marius Siahaan, Suhadak, Siti Ragil Handayani, Solimun .2014. The Influence of Company Size and Capital Structure towards Liquidity,Corporate Performance and Firm Value, for Large and Small Group Companies European. Journal of Business and Management www.iiste.org ISSN 2222-1905 (Paper) ISSN 2222-2839 (Online) Vol.6, No.18, 2014

Undang-undang no 20 Tahun 2008.

Wahyuni, Sri. 2012. Efek Struktur Modal Terhadap Profitabilitas pasa Perusahaan Manufaktur yang Terdaftar di Bursa Efek Indonesia. Management Analysis Journal, 1 (2), h: 2933
Weston, J. Fred \& Copeland, Thomas E. 1997. Manajemen Keuangan. Jilid 2, Edisi 9, Binarupa Aksara. Jakarta.

Weston, J.F dan Copeland. 2008. Dasar-Dasar Manajemen Keuangan Jilid II. Jakarta : Erlangga.

Widyantari, Ni Luh Putu dan I Putu Yadnya. 2017. Pengaruh Struktur Modal, Profitabilitas Dan Ukuran Perusahaan Terhadap Nilai Perusahaan Pada Perusahaan Food And Baverage Di Bursa Efek Indonesia. E-Jurnal Manajemen Unud, Vol. 6, No. 12, 2017: 6383-6409

Wirawan ,Putu Artha.2017. Pengaruh Struktur Aktiva, Profitabilitas, Ukuran Perusahaan Dan Likuiditas Terhadap Struktur Modal Pada Perusahaan Sektor Barang Konsumsi Yang Terdaftar Di Bursa Efek Indonesia Periode Tahun 2014- 2015. Jurnal Pendidikan Ekonomi Undiksha Volume 9 No.1 Tahun: 2017 p-ISSN : 2599-1418 e-ISSN : 25991426

www.idx.co.id

www.finance.yahoo.com 
